\title{
PENGARUH MODEL PEMBELAJARAN BERBASIS MASALAH DAN \\ MOTIVASI BELAJAR TERHADAP KEMAMPUAN MENULIS ARGUMENTASI SISWA SMA FITRA ABDI PALEMBANG \\ Oleh \\ Irwansa \\ Irwansyah.pps@gmail.com \\ Pascasarjana UPGRI Palembang
}

\begin{abstract}
The purpuse of this research was to determine model of Problem-Based Learning and Learning Motivation toward writing argumentation's ability before using the problem-based learning. This research used the method of experimental method. The population of this research is the all students in the tenth grade of SMA Fitra Abdi Palembang with the total number 116 students and the total of the data sample of this research is 68 students. Based on the above, the writer used two-way anova analysis. Besides, the writer also found the result of this research: (1) there was a significant difference in writing ability between student who tought by using problem-based learning and conventional learning. Where the result was 0,00 it means that the result was lower than significant level $(0,05)$ and (2) there was an interaction effect toward writing argumentation's ability where the result of this research is 3,915, it means that higher than $F_{\text {tab }}(3,32)$ with the significant level $(0,05)$
\end{abstract}

Keywords: Problem-based learning, motivation, writing argumentation

\section{PENDAHULUAN}

Belajar hakikatnya adalah suatu proses yang ditandai dengan adanya perubahan pada diri seseorang, dan perubahan sebagai hasil dari proses belajar dapat diindikasikan dalam berbagai bentuk seperti berubah pengetahuan, pemahaman, sikap dan tingkah laku, kecakapan, keterampilan dan kemampuan serta perubahan aspekaspek yang lain yang ada pada individu yang belajar (Trianto, 2009:9).

Pembelajaran adalah upaya secara sistematis yang dilakukan guru untuk mewujudkkan proses pembelajaran berjalan secara efektif dan efisien yang dimulai dari perencanaan, pelaksanaan, dan evaluasi (Aqib, 2014:66). Dalam pembelajaran bahasa
Indonesia Ada empat aspek keterampilan menulis yang harus dikuasai secara seimbang oleh siswa, menyimak, berbicara, membaca dan menulis. Dari keempat keterampilan berbahasa tersebut menulis berada pada urutan terakhir, artinnya jika seseorang dapat menguasai keterampilan menulis berati orang tersebut telah menguasai keterampilan menyimak, berbicara, dan membaca.

Kemampuan menulis khususnya menulis argumentasi merupakan suatu suatu kompetensi yang dimiliki oleh siswa. Menurut Tarigan (2008:3), menulis merupakan suatu keterampilan berbahasa yang dipergunakan untuk berkomunikasi secara tidak langsung dengan orang lain dan menulis suatu 
kegiatan yang produktif dan ekspresif. Menurut Semi (2007:14), menulis merupakan suatu proses kreatif memindahkan gagasan ke dalam lambang-lambang tulisan. Dalam pengertian ini menulis memiliki tiga aspek utama, (1) adanya tujuan atau maksud tertentu (2) adanya gagasan atau sesuai yang hendak dikomunikasikan, dan (3) adanyan sistem pemindahan gagasan yaitu berupa sistem bahasa.

Menulis merupakan komunikasi tidak langsung yang berupa pemindahan pikiran atau perasaan dengan memanfaatkan grafologi, struktur bahasa, dan kosakata dengan menggunakan simbol-simbol sehingga dapat dibaca seperti apa yang diwakili oleh simbol-simbol (Depdiknas,2009:5). Suparno (2009:13) mengemukakan bahwa menulis adalah sebagai suatu kegiatan penyampaian pesan dengan menggunakan bahasa tulis sebagai alat atau medianya.

Argumentasi adalah karangan yang terdiri dari atas paparan alasan dan penyeintesisan pendapat untuk membangun suatu kesimpulan (Suparno, 2009:5.36). Menurut Somad dkk (2008:192), argumentasi adalah karangan yang memberikan alasan kuat dan menyakinkan, dalam argumentatif penulis menyampaikan pendapat yang disertai penjelasan dan alasan yang kuat dengan maksud agar pembaca terpengaru. Menurut Budiharso (2009:26), argumentasi adalah esai yang bertujuan untuk mengubah pikiran atau tindakan orang lain dengan menggunakan bukti-bukti yang dapat diterima akal. Argumentasi ialah mempengaruhi, mengubah pendapat, sikap atau tingkah laku bahkan mengoyahkan keyakinan pembaca atau keseluruhan pendengarnya dan mengubah pendapat dilakukan dengan memberikan argumen-argumen yang logis sehingga dapat dipercaya kebenarannya (Zaemar dan Harahap, 2011:44).

Penelitian ini tidak hanya meneliti model pembelajaran saja, tetapi dikaitkan dengan pula pada motivasi belajar siswa dalam menulis argumentasi. Kemampuan menulis argumentasi dapat dikaitkan dengan SMA Fitra Abdi Palembang motivasi belajar siswa. Motivasi pada hakikatnya ada dua yang dibahas dari sudut pandang yaitu, motivasi intrinsik dan motivasi ekstrinsik. Motivasi intrinsik adalah motif yang menjadi aktif tidak perlu dirangsang karena dalam setiap individu sudah ada dorongan untuk melakukan sesuatu. Sedangkan motivasi ekstrinsik merupakan motif-motif aktif dan berfungsi karena adanya dorongan dari luar. Tujuannya motif ekstrinsik agar anak didik mau belajar,untuk 
memotivasi anak didik untuk belajar (Djamarah (2008:149).

Dalam artikel ini dibahas,

apakah Terdapat perbedaan kemampuan siswa menulis argumentasi siswa yang belajar dengan menggunakan model pembelajaran berbasis masalah dengan menggunakan model pembelajaran konvensional? (2) apakah terdapat interaksi antara model pembelajaran berbasis masalah dan motivasi belajar terhadap kemampuan menulis argumentasi?

Penelitian ini diharapkan dapat bermanfaat baik secara teoretis maupun praktis dalam meningkatkan mutu pendidikan. Secara teoritis diharapkan agar penelitian ini dapat menambah ilmu pengetahuan bidang kebahasaan khususnya menganai keterampilan menulis argumentasi dengan menggunakan model pembelajaran berbasis masalah.

Secara praktis diharapkan penelitian ini bermanfaat sebagai berikut.

1. Bagi siswa, untuk memudahkan siswa dalam belajar dan berlatih meningkatkan keterampilan menulis, dalam hal ini menulis argumentsi.

2. Bagi guru, diharapkan dapat menjadi inspirasi dalam memilih, mengembang- kan, dan mengimplementasikan metode atau model pembelajaran sesuai dengan kompetensi yang akan dicapai.

3. Bagi sekolah, diharapkan dapat memberikan masukan, tentang pembelajaran dan upaya peningkatan kreativitas siswa yang berimbas pada peningkatan kualitas pendidikan di sekolah.

\section{KAJIAN TEORETIK}

Menurut Stenrberg (dikutip Wardarita, 2014:13), kemampuan adalah untuk menunjukkan suatu tindakan khusus atau tugas khusus baik secara fisik maupun mental. Kemampuan merupakan hasil belajar yang diperoleh pembelajar setelah mengikuti suatu pembelajaran (Wardarita,2014:13). Menurut Dalman (2016:3), menulis adalah suatu kegiatan komunikasi berupa penyampaian pesan secara tertulis kepada pihak lain dengan menggunakan bahasa tulis sebagai alat atau medianya.

Menulis merupakan menyusun tanda-tanda tulis (Graphic syimbols) yang menyatakan suatu bahasa yang diketahui oleh seseorang, sehingga orang lain dapat membaca tanda-tanda tulis jika mereka mengenalnya dan mengerti bahasanya (Wardarita, 2015:4). Menulis merupakan suatu keterampilan berbahasa yang dipergunakan untuk berkomunikasi secara tidak langsung dengan orang lain, dan menulis sutu 
kegiatan yang produktif dan ekspresif (Tarigan, 2008:3). Menurut Semi (2007:14), menulis merupakan suatu proses kreatif memindahkan gagasan ke dalam lambang-lambang tulisan. Dalam pengertian ini menulis memiliki tiga aspek utama, (1) adanya tujuan atau maksud tertentu (2) adanya gagasan atau sesuai yang hendak dikomunikasikan, dan (3) adanyan sistem pemindahan gagasan yaitu berupa sistem bahasa.

Menurut Dalman (2016:137) mengemukakan bahwa argumentasi merupakan jenis karangan yang dapat membuat pembaca merasa percaya dengan pendapat/argumen penulisnya. Menurut Suparno (2009:5.36), argumentasi adalah karangan yang terdiri dari atas paparan alasan dan penyintesisan pendapat untuk membangun suatu kesimpulan. Menurut Somad, Dkk (2008:192), argumentasi adalah karangan yang memberikan alasan kuat dan menyakinkan, dalam argumentasi penulis menyampaikan pendapat yang disertai penjelasan dan alasan yang kuat dengan maksud agar pembaca terpengaruh. Menurut Zaemar dan Harahap (2011:44), argumentasi adalah mempengaruhi, mengubah pendapat, sikap atau tingkah laku bahkan mengoyahkan keyakinan pembaca atau keseluruhan pendengarnya dan mengubah pendapat dilakukan dengan memberikan argumen-argumen yang logis sehingga dapat dipercaya kebenarannya. Argumentasi ialah esai yang bertujua untuk mengubah pikiran atau tindakan orang lain dengan menggunakan bukti-bukti yang dapat diterima akal (Budiharso, 2009:26).

\section{a. Hakikat Model Pembelajaran Berbasis Masalah}

Model pembelajaran berbasis masalah merupakan salah satu alternatif pembelajaran yang memungkinkan dikembangkannya keterampilan berpikir siswa (penalaran, komunikasi, dan koneksi) dalam memecahkan masalah. Hamdayama (2014:209) mengemukakan model pebelajaran berbasis masalah merupakan rangkaian aktivitas pembelajaran yang menekankan proses penyelesaian masalah yang dihadapi secara ilmiah. Menurut Tan (Muriyati dan Kusumaningsih, 2011:98), model Pembelajaran berbasis masalah (PBM) berkaitan dengan penggunaan intelegensi dari dalam diri individu yang berada dalam sebuah kelompok orang atau lingkungan untuk memecahkan masalah yang bermakna, relevan, dan kontekstual. Menurut Kosasih (2015: 88), model pembelajaran berbasis masalah adalah model pembelajaran yang berdasar pada masalah-masalah yang dihadapi siswa terkait dengan KD yang sedang dipelajari siswa.

Berdasarkan beberapa pengertian di atas, dapat disimpulkan 
bahwa model pembelajaran berbasis masalah adalah suatu model pembelajaran yang dapat digunakan oleh guru agar tercipta susana pembelajaran di dalam kelas yang menyenangkan untuk memecahkan suatu masalah dalam proses pembelajaran.

\section{b. Ciri-Ciri Khusus Model}

\section{Pembelajaran Berbasis Masalah}

Menurut Barrow (2005), strategi pembelajaran berbasis masalah terdapat tiga ciri utama yaitu sebagai berikut.

1) Model pembelajaran berbasis masalah merupakan rangkaian aktivitas pembelajaran, artinya melalui model pembelajaran berbasis masalah siswa aktif berpikir, berkomunikasi, mencari dan mengolah data dan akhirnya menyimpulkannya.

2) Kedua, aktivitas pembelajaran diarahkan untuk menyelesaikan masalah. Model pembelajaran berbasis masalah menempatkan masalah sebagai kata kunci dari proses pembelajaran.

3) Pemecahan masalah dilakukan dengan menggunakan pendekatan berpikir secara ilmiah. Berpikir dengan menggunakan metode ilmiah adalah proses berpikir deduktif dan induktif.

\section{b. Motivasi Belajar}

Menurut Fathurrohman dan Sutikno (2010:19), motif adalah sebagai daya penggerak yang ada di dalam diri seseorang untuk melakukan aktivitas tertentu untuk mencapai suatu tujuan. Motif itu merupakan suatu kondisi internal. Menurut Sardiman (2010:73), motif merupakan sebagai upaya mendorong seseorang untuk melakukan sesuatu.

Menurut Djamarah (2008:148) mengemukakan bahwa motivasi merupakan suatu perubahan energi di dalam pribadi seseorang yang ditandai dengan timbulnya perasaan dan reaksi untuk mencapai suatu tujuan. Perubahan energi dalam diri seseorang itu berbentuk suatu aktivitasyang nyata yang berupa kegiatan fisik. Menurut Schunk, dkk. (2012:62), motivasi merupakan suatu proses dan inisiasikannya dan dipertahankannya aktivitas yang diartikan pada pencapaian tujuan. Sebagai proses motivasi berfungsi sebagai pendorong, pengarah, dan pengerak tingkah laku. Motivasi mempunyai nilai dalam menetukan keberhasilan seseorang.

Dilihat dari sumbernya, motivasi belajar ada dua jenis, yaitu motivasi intrinsik dan motivasi ekstrinsik.

\section{1) Motivasi Intrinsik}

Motivasi intrinsik adalah motivasi yang hidup dalam diri pembelajar dan berguna dalam situasi belajar yang fungsional. Hal ini pujian atau hadiah tidak diperlukan karena tidak akan 
menggerakkan pembelajar untuk belajar. Motivasi intrinsik berjenis motivasi yang timbul dari dalam diri individu sendiri tanpa ada paksaan dorongan orang lain, tetapi atas dasar kemauan sendiri.

2) motivasi ekstrinsik merupakan motivasi yang timbul sebagai akibat pengaruh dari luar individu (Fathurrohman dan Sutikno, 2010:19-20).

\section{METODOLOGI PENELITIAN}

Metode dalam penelitian ini adalah metode eksperimen. Penelitian eksperimen ini dilakukan untuk memperoleh jawaban atas hipotesis yang telah disusun. Menurut Arikunto (2010:9), metode eksperimen adalah suatu cara untuk mengetahui ada tidaknya akibat dari suatu yang dikenakan pada subjek yang diselidiki. Percobaan yang dimaksud adalah membandingkan antara dua kelompok sasaran dalam penelitian. Menurut Sugiyono (2008:72), metode eksperimen merupakan sebagai metode penelitian yang digunakan untuk mencari pengaruh perlakuan tertentu terhadap yang lain dalam kondisi yang diperlakukan.
Metode penelitian ialah sebagai usaha untuk menemukan, mengembangkan, dan menguji kebenaran suatu pengetahuan yang dilakukan dengan menggunakan metode-metode ilmiah (Hadi, 2004:4).

Kelompok eksperimen dalam penelitian ini adalah kelompok siswa yang memperoleh pengajaran menulis argumentasi dengan menggunakan model pembelajaran berbasis masalah, sedangkan kelompok kontrol siswa yang memperoleh pengajaran menulis argumentasi dengan menggunakan model pembelajaran konvensional.

\section{HASIL PENELITIAN DAN PEMBAHASAN}

Perhitungan hasil akhir kelas eksperimen penelitian menunjukkan $F_{\text {hitung }}$ untuk pengaruh dalam kolom model pembelajaran sebesar 1,532 lebih besar dari $\mathrm{F}_{\text {tabel }} 2,76$ pada taraf nyata $\alpha=$ $0,05\left(F_{\text {hitung }} 1,532>F_{\text {tabel }}=2,76\right)$. Nilai tertinggi yang diperoleh siswa 87 dan nilai terendah 74 dengan range 13 . Dengan nilai rata-rata 79,18 standar deviasi 3,000 dan variance 8,998. Untuk melihat lebih jelas kemampuan menulis argumentasi pada siswa yang belajar 
dengan menggunakan model pembelajaran berbasis masalah.

Hasil tes akhir kelas kontrol Jumlah siswa kelas kontrol sebanyak 34 orang. Nilai tertinggi yang diperoleh siswa 81 dan nilai terendah 70 dengan range 11 . Dengan nilai rata-rata 75 , standar deviasi 3,140 dan variance 9,862. Kemampuan menulis argumentasi siswa yang belajar dengan menggunakan model pembelajaran berbasis masalah pada kelompok siswa yang memiliki motivasi belajar tinggi diketahui bahwa skor terendah 76 dan skor tertinggi 87. Skor nilai rata-rata adalah 80,47 median 80,00 , range 11 dan standar deviasi sebesar 3,223 Varian 10,390 .

Kemampuan menulis argumentasi siswa yang belajar dengan menggunakan model pembelajaran berbasis masalah pada kelompok siswa yang memiliki motivasi belajar tinggi diketahui bahwa skor terendah 76 dan skor tertinggi 87. Skor nilai rata-rata adalah 80,47 median 80,00 , range 11 dan standar deviasi sebesar 3,223 Varian 10,390 Kemampuan menulis argumentasi siswa yang belajar dengan menggunakan model pembelajaran berbasis masalah pada kelompok siswa yang memiliki motivasi belajar rendah diketahui bahwa skor terendah 72 dan skor tertinggi 79 . Skor nilai rata-rata adalah 75,53, median 75,00 dan standar deviasi sebesar 2,065.

Kemampuan

Menulis argumentasi siswa yang belajar dengan menggunakan model pembelajaran konvensional yang memiliki motivasi belajar tinggi diketahui bahwa skor terendah 71 dan skor tertinggi 81 dengan range 10 . Skor rata-rata adalah 76,47 , dengan median 77,00 dan standar deviasi sebesar 3,204. Varian 10,265 Kemampuan menulis argumentasi yang belajar dengan menggunakan model pembelajaran konvensional pada siswa yang memiliki motivasi belajar rendah diketahui bahwa skor nilai terendah 70 dan skor nilai tertinggi 80 . Dengan nilai rata-rata adalah 74,88 , median 74,00 , dan standar deviasi 2,950, range 10 .

1. Perhitungan hasil perhitungan diperoleh $\mathrm{F}_{\text {hitung }}$ untuk pengaruh dalam kolom model pemebelajaran sebesar 1,532 lebih besar dari $\mathrm{F}_{\text {tabel }}$ 2,76 pada taraf nyata $\alpha=0,05$ ( $F_{\text {hitung }}$ $\left.1,532>\mathrm{F}_{\text {tabel }}=2,76\right)$ artinya hipotesis $\mathrm{H}_{\mathrm{o}}$ ditolak sedangkan $\mathrm{H}_{\mathrm{a}}$ diterima kebenarannya. Hal ini membuktikan adanya pengaruh yang signifikan antara kemampuan siswa menulis argumentasi dengan menggunakan 
2. model pembelajaran berbasis masalah dengan model pembelajaran konvensional.

3. Hasil analisis uji Independent sample T-Test dapat dilihat diperoleh bahwa nilai signifikan (2-tailed) sebesar 0,01 lebih kecil dari 0,05 Sehingga terdapat perbedaan pengaruh yang signifikan hipotesis $\mathrm{H}_{0}$ ditolak, sedangkan $\mathrm{H}_{\mathrm{a}}$ diterima kebenarannya. Hal ini membuktikan bahwa terdapat perbedaan antara siswa yang belajar dengan menggunakan model pembelajaran konvensional.
4. Hasil analisis uji Independent sample T-Test di atas, dapat dilihat diperoleh bahwa nilai signifikan (2-tailed) sebesar 0,04 lebih kecil dari 0,05 Sehingga terdapat perbedaan pengaruh yang signifikan hipotesis $\mathrm{H}_{0}$ ditolak, sedangkan $\mathrm{H}_{\mathrm{a}}$ diterima kebenarannya. Hal ini membuktikan bahwa terdapat perbedaan antara siswa yang belajar dengan menggunakan model pembelajaran konvensional

Tabel Hasil Analisis Varian

Tests of Between-Subjects Effects

Dependent Variable: Menulis

\begin{tabular}{|l|r|r|r|r|r|r|}
\hline Source & \multicolumn{1}{|c|}{$\begin{array}{c}\text { Type III } \\
\text { Sum of } \\
\text { Squares }\end{array}$} & Df & Mean Square & F & Sig. & $\begin{array}{c}\text { Partial Eta } \\
\text { Squared }\end{array}$ \\
\hline Corrected & $53,598^{\mathrm{a}}$ & 12 & 4,467 & 1,870 &, 101 &, 517 \\
Model & 110882,844 & 1 & 110882,844 & 46416,07 &, 000 & 1,000 \\
Intercept & 32,928 & 9 & 3,659 & 1,532 &, 201 &, 396 \\
PBM & 8,758 & 1 & 8,758 & 3,666 &, 069 &, 149 \\
Motivasi & 18,706 & 2 & 9,353 & 3,915 &, 036 &, 272 \\
PBM * Motivasi & 50,167 & 21 & 2,389 & & & \\
Error & 184516,000 & 34 & & & & \\
Total & 103,765 & 33 & & & & \\
Corrected Total & & & & & & \\
\hline
\end{tabular}

a. $\mathrm{R}$ Squared $=, 517$ (Adjusted R Squared $=, 240$ ) 
Tabel Anova Dua Jalur

\begin{tabular}{|c|c|c|c|c|}
\hline Sumber Variansi & $\begin{array}{c}\text { Jumlah } \\
\text { Kuadrat }\end{array}$ & $\begin{array}{c}\text { Derajat } \\
\text { Kebebasan }\end{array}$ & $\begin{array}{c}\text { Rata-rata } \\
\text { Jumlah } \\
\text { Kuadrat }\end{array}$ & $\mathbf{F}_{\text {hitung }}$ \\
\hline PBM & 3,659 & 9 & 3,659 & 1,532 \\
\hline Motivasi & 8,758 & 1 & 8,758 & 3,666 \\
\hline Interaksi AxB & $\mathbf{9 , 3 5 3 s}$ & $\mathbf{2}$ & $\mathbf{9 , 3 5 3}$ & $\mathbf{3 , 9 1 5}$ \\
\hline Dalam Kelompok & 2,389 & 21 & 2,389 & \\
\hline Total & 103,765 & 33 & & \\
\hline
\end{tabular}

5. Berdasarkan perhitungan Anova dapat dilihat bahwa $\mathrm{F}$ hitung untuk faktor interaksi 3,915 lebih besar dari $F$ Tabel 3,32 dengan taraf signifikan 0,05. Hal ini berarti terdapat pengaruh interaksi antara model pembelajaran berbasis masalah dan motivasi belajar tinggi dan rendah terhadap kemampuan menulis argumentasi. Dengan demikian, hipotesis $\mathrm{H}_{0}$ di tolak. Jadi ada interaksi antara model pembelajaran berbasis masalah dengan motivasi belajar terhadap kemampuan menulis menulis argumentasi siswa kelas $\mathrm{X}$ SMA Fitra Abdi Palembang.

\section{SIMPULAN DAN SARAN}

Berdasarkan hasil pengujian hipotesis dan pembahasan, dibuktikan bahwa secara kesuluruhan, kemampuan menulis argumentasi siswa yang belajar dengan model pembelajaran berbasis masalah lebih baik dibandingkan dengan menggunakan model pembelajran konvensional. Simpulkan dari penelitian ini adalah sebagai berikut.

1. Terdapat pengaruh kemampuan menulis argumentasi siswa yang belajar dengan menggunakan model pembelajaran berbasis masalah dengan model pembelajaran konvensional

2. Terdapat perbedaan kemampuan menulis argumentasi siswa yang memiliki motivasi belajar tinggi yang menggunakan model pembelajaran berbasis masalah dan siswa yang belajar menggunakan model pembelajaran konvensional.

3. Terdapat pengaruh kemampuan menulis argumentasi siswa yang memiliki motivasi belajar rendah yang meggunakan model pembelajaran berbasis masalah dan siswa yang belajar menggunakan model pembelajaran konvensional 


\section{SARAN}

1. Model pembelajaran berbasis masalah dapat dijadikan sebagai sebagai model alternatif dalam peroses pembelajaran menulis argumentasi untuk mencapai hasil belajar yang optimal. Dengan penggunaan model pembelajaran berbasis masalah diharapkan kemampuan siswa dalam pembelajaran menulis argumentasi meningkat.

2. Untuk mengembangkan materi pembelajaran bahasa Indonesia khususnya dalam menulis

\section{DAFTAR PUSTAKA}

Aqib, Zainal. 2014. Model-Model Media dan Strategi Pembelajaran Kontekstual (Inovatif). Bandung:Yrama Widia.

Arikunto, Suharsimi. 2010. Prosedur Penelitian Suatu Pendekatan Praktik. Jakarta: PT. Rineka Cipta.

Barrow, Min Liu (2005) Jurnal Ilmiah Didaktika Vol. XIV, No. 1, Agustus 2013

Budiharso. 2009. Panduan Lengkap Penulisan Karya Ilmiah. Yogyakarta.Venus.

Dalman. 2016. Keterampilan Menulis. Jakarta: Rajawali Pers.

Depdiknas. 2009. Keterampilan Menulis. Jakarta.

Djamarah, Syaiful Bahri. 2008. Psikologi Sastra. Jakarta: Renika Cipta argumentasi, hendaknya guru mampu mempertimbangkan manfaat bagi siswa dalam kehidupan sehari-hari.

3. Perlu dilakukan penelitian lebih lanjut yang sejenis, dengan variabel yang berbeda dan lebih banyak lagi, untuk melihat seberapa besar pengaruh model pembelajaran berbasis masalah dan motivasi belajar dalam kegiatan menulis

4. Bagi siswa perlu meningkatkan pemahaman dan pengetahuan serta pengembangan minat terhadap motivasi belajar serta kerterampilan dalam menulis. Khususnya menulis argumentasi.

Fathurrohman Pupu dan Sutikno Sobry. $\begin{array}{llr}2010 . \quad \text { Strategi } & \text { Belajar } \\ \text { Mengajar. } & \text { Bandung: } & \text { Refika } \\ \text { Aditama. } & & \end{array}$

Hadi, Sutrisno. 2004. Metodologi Research. Yogyakarta: Andi.

Hamdayama. 2014. Model dan Metode Pembelajaran Kreatif dan Berkarakter. Jakarta: Ghalia Indonesia.

Kosasih. 2015. Strategi Belajar dan Pembelajaran Implementasi Kurikulum 2013. Bandung: Yrama Widiya.

Muriyati dan Kusumaningsih, 2011. Strategi Pembelajaran Bahasa Indonesia. Sukoharjo: Univet Bantara Press

Sardiman 2010. Interakasi dan Motivasi Belajar Mengajar. Jakarta: Rajawali Pers. 
Schunk, dkk.2012. Motivasi dalam Penelitian (teori, penilaian, dan amplikasi). Jakarta: PT. Indeks.

Semi M. Atar. 2007. Dasar-Dasar Keterampilan Menulis.Bandung. Angkasa.

Somad, Dkk. 2008. Aktif dan Kreatif Berbahasa Indonesia. Jakarta: Pusat Pembukuan Departemen Pendidikan Nasional.

Sugiyono. 2008. Metode Penelitian Kualitatif Kuantitatif dan $R \& D$. Bandung: Alfabeta.
Suparno, Dkk. 2009. Keterampilan Menulis. Jakarta: Universitas Terbuka.

Tarigan, Henry Guntur. 2008. Menulis Sebagai Suatu Keterampilan Berbahasa. Bandung: Angkasa Bandung.

Trianto. 2009. Mendesain Model Pembelajaran InovatifProgresif. Jakarta: Kencana. 
